\title{
Community Participation: How the population contributes to urban planning and cities' development in Brazil and Portugal
}

\author{
Participação comunitária: como a população contribui para \\ o planejamento urbano e o desenvolvimento das cidades no \\ Brasil e em Portugal
}

\author{
Participación comunitaria: Cómo la población contribuye a la \\ planificación urbana y al desarrollo de las ciudades en Brasil y \\ Portugal
}

\author{
Ana Guimarães \\ anaguimaraes@gmail.com \\ Universidade do Porto, Portugal
}

\begin{abstract}
The urban environment, understood as the environment changed by man, is represented by the city as a space for coexistence of individuals, endowed with an entire infrastructure composed of public goods and services, which aim at the wellbeing of its inhabitants. When people effectively participate in decision-making interest in cities, they feel more responsible for the outcome of their decisions, providing a political maturity of the population. In both Brazil and Portugal, the Master Plan is the main instrument for planning and regulating cities and the urban environment. The difference between them may lie in the fact that Brazil is one step ahead with popular participation in urban planning and participatory budgeting, probably due to the political and socio-economic characteristics of the country, and the needs that this condition imposes on its inhabitants. Regardless of both Brazil and Portugal already make great efforts in this direction, and the question of community involvement in the decision-making process, urban planning, and participatory budgeting is already addressed and considered (although at different levels, stages, and legal formalization), there is still much to be done in this direction to ensure the effective participation of the population in the construction and evolution of cities.
\end{abstract}

Keywords: Participatory budget; Community involvement; Urban planning; Public consultations.

Resumo: O ambiente urbano, entendido como o ambiente alterado pelo homem, é representado pela cidade como espaço de convivência dos indivíduos, dotado de toda uma infra-estrutura composta por bens e serviços públicos, que visam o bemestar de seus habitantes. Quando as pessoas participam efetivamente do interesse pela tomada de decisões nas cidades, elas se sentem mais responsáveis pelo resultado de suas decisões, proporcionando uma maturidade política da população. Tanto no Brasil quanto em Portugal, o Plano Diretor é o principal instrumento de planejamento e regulamentação das cidades e do meio urbano. A diferença entre eles pode estar no fato de que o Brasil está um passo à frente em relação à participação popular no planejamento urbano e no orçamento participativo, provavelmente devido às características políticas e socioeconômicas do país, e às necessidades que essa condição impõe aos seus habitantes. Independentemente de Brasil e Portugal já fazerem grandes 
esforços nesse sentido, e a questão do envolvimento da comunidade no processo de tomada de decisão, planejamento urbano e orçamento participativo já é abordada e considerada (embora em diferentes níveis, estágios e formalização legal), ainda há muito a ser feito nesse sentido para garantir a participação efetiva da população na construção e evolução das cidades.

Palavras-chave: Orçamento participativo; envolvimento da comunidade; planejamento urbano; consultas públicas.

Resumen: El entorno urbano, entendido como el entorno cambiado por el hombre, está representado por la ciudad como un espacio para la convivencia de individuos, dotado de una infraestructura completa compuesta por bienes y servicios públicos, que apuntan al bienestar de sus habitantes. Cuando las personas participan efectivamente en el interés de la toma de decisiones en las ciudades, se sienten más responsables del resultado de sus decisiones, proporcionando una madurez política de la población. Tanto en Brasil como en Portugal, el Plan Maestro es el principal instrumento para planificar y regular las ciudades y el entorno urbano. La diferencia entre ellos puede radicar en el hecho de que Brasil está un paso adelante en relación con la participación popular en la planificación urbana y el presupuesto participativo, probablemente debido a las características políticas y socioeconómicas del país, y las necesidades que esta condición impone a su habitantes Independientemente de que Brasil y Portugal ya realicen grandes esfuerzos en esta dirección, y la cuestión de la participación de la comunidad en el proceso de toma de decisiones, la planificación urbana y el presupuesto participativo ya se abordan y consideran (aunque en diferentes niveles, etapas y formalización legal), existe Todavía queda mucho por hacer en esta dirección para garantizar la participación efectiva de la población en la construcción y evolución de las ciudades.

Palabras clave: Presupuesto participativo; participación comunitaria; planificación urbana; consultas públicas.

\section{INTRODUCTION}

Involving the community and promoting popular participation in the instruments of urban planning and regulation has been fundamental for a system to be implemented and successful in today's cities. Studying how the instruments of planning and regulation emerged, were constituted and evolved over the years, and above all how popular participation is approached and has been gaining ground in this scenario, how it involves and reconciles the various actors and interests that interact in the city, and how it can deliver better results is also an important way to develop new tools for urban planning and regulation, to bring better results.

It's known that different locations and different communities require different solutions, appropriate for each case. Thus, what works in one city and for one community may not work elsewhere and for other people. However, policies must ensure the necessary conditions for the mechanisms of urban planning to take place effectively.

This paper aims to identify, analyze, and compare the forms of popular participation in urban planning between Brazil and Portugal, within the social and historical context of each country. For this purpose, information was gathered through published material. 
Furthermore, through a doctrinal analysis, aims to demonstrate the importance of planning the performance of the Public Power, to direct urban policies to guarantee the well-being of individuals, following the principle of the social function of the city. It also intends to attest to the essentiality of the shared management of the city, thus demonstrating the potential of public audiences in the efficient management of urban spaces, promoting the transparency of political decisions, with the aim of social justice, emphasizing the essentiality of effective popular participation in the elaboration and updating of the Master Plan, leading to a democratic and efficient management of the city, legitimizing the performance of the public power, which must be closely linked to social desires.

This work seeks to analyze participatory management in the urban environment in the construction of an integrating society and the management directed at the implementation of effective public policies to guarantee the well-being of all. And regardless of the particularities of a country, city or region, these are universal requirements for any urban territory oriented for the quality of life, holistic development, and social relations.

\section{URBAN PLANNING AND POPULAR PARTICIPATION}

The urban environment, understood as the environment changed by man, is represented by the city (MARQUES, 2010) as a space for coexistence of individuals, endowed with an entire infrastructure composed of public goods and services, which aims at the well-being of its inhabitants. According to Fiorillo (2013, p. 79), the artificial environment "is directly related to the concept of the city", understood, therefore, as an urban space of social coexistence and human activities. In this sense, the city is understood as the natural habitat of man, where individuals exercise their capacities and skills. The city reveals itself as the center of human life, which demands special attention from the State regarding the development of the individual capacities, providing the necessary means to guarantee the basic rights of people.

Although understood as the core of the artificial environment (COSTA, RIOS, 2013) and indispensable to human existence with dignity, it is now increasingly apparent that the city understood as the necessity of the other, presents itself as a means of social segregation, which generates environmental impacts.

There was growing negligence for socio-environmental issues in the face of urban development, especially as regards the irregularities of land subdivision and occupation, the degradation of nature, the exacerbated consumption, and the lack of planning of the public policies. This one currently (or just a few years ago) focus(ed) primarily on the economic growth, with an intensification of the environmental crisis and social inequalities, implying consequently in deterioration of the quality of urban life (RUMBLE et al., 2019). In this sense, it is evident that the relationship between the environment and socio-economic development is fractured, due to economic and technological progress unfamiliar to environmental and social issues. 
The economic development based on the scientific rationality implies in the absence of public policies aimed at the fulfillment of social desires, thus leading to the growing exclusion of minorities and the absence of planning for adequate urban development. Regarding this Marques (2010, p.91) maintains that "a city created to meet man's needs and provide him with well-being and security has turned out to be an important element against him acts, deteriorating their quality of life".

Urban planning, even when performed by recognized experts, should take into account the human aspects involved, directly and indirectly, being the man the fundamental planning object, and the quest for dignity and quality of life. Objectively, no design or planning options could be adequately justified if there are no communication alternatives for the community to be heard and their needs met. Their contribution is indispensable for carrying out any planning action.

It is up to the person responsible for urban planning to establish channels, tools, and filters for the democratic and contributory participation of citizens, not only in the plan but in all stages of its application, as an ever-present and living process. Therefore, there is a need to consider the participatory and political, social, and economic issues that affect or may affect them related to urban planning.

Cities have their idiosyncrasies and identities. Each city has its strength and power structure, and this should be considered in the elaboration of planning, with observations that strongly consider their reality, more than theoretical and rhetorical formulations. It is also observed that new forces with greater character involve themselves and are demanding constructive responses. The rigidity of systems and disciplined classifications give way to the unpredictable where are timely achieved to address their shortcomings.

Therefore, it is urgent to consider planning as a legal guideline and not just as productive actions, within a plurality of unforeseeable circumstances, or even not desired ones. The cities also follow their Life Cycle, the so-called "S" curve, time-altered by the change of some of its influence factors. As can be seen, the urban planning should be aware towards the perception of the new, addressed in the proposal to establish a better understanding of the urban planning offers, counting on the contribution of citizens. That is, neither policy inconstancy nor rigidity of action - planning should move in a controlled environment, where the revisability of management's actions is duly weighed, but adopted as and when necessary.

Faced with such a framework regarding the development of cities and as well as protecting the environment and guarantee of social rights, it is necessary to change the position of both, individuals and public administration, through environmental education over effective public policies that guarantee the well-being of all.

It is clear that public policies for urban development must be attentive to these implications, which is supported by Milaré's (2011, p. 345) idea that "once we accept the holistic character of the environment as a product of the interactions and relations of human society with the natural world, the built environment, or artificial, becomes the subject of environmental policies". 
In this way, the city can no longer be conceived as a means of generating environmental and social impacts, because of the overvaluation of individual rights, but must be understood as means of guaranteeing the right to life dignity, emerging hence the social function of the city (FIORILLO, 2013). Indeed, aspirations for the sustainable development of the urban environment cannot be thrived without giving the cities a minimum infrastructure capable of guaranteeing individuals a decent life, obviously corresponding to the balance of the environment, vital to human life. Thus, planning must be conceived as an ongoing process that requires an efficient follow-up and monitoring system and which reflects the interactive confrontation between the proposals - the plan - and its implementation concrete management - to print adaptive to planning, through successive adjustments, in which the private sector is indisputable.

The strengthening of democratic instruments of urban planning and management enables the participation of civil society in the elaboration of urban policies, directing the performance of the Public Power in the concrete and effective care of the social longing for a life with quality. The practice of planning, rather than establishing ideal models for the functioning of cities, must contemplate conflicts and have a function of correcting the imbalances of all orders that are caused by urbanization, promoting a reading of the real city. Hence it is the importance of being elaborated through a democratic process, ensuring the participation of the population and representative associations of the various segments of the community.

The strength and consistency of the Administration's action are not demonstrated, however, by its closure concerning the exterior, especially to the addressees of their action (the citizens). Fur, otherwise, the ability to adapt and impose planning policies by the Administration takes by promoting greater openness, by fostering dialogue and building on policies and drawing up plans in which all those who are touched by them are reviewed. The need to establish a constructive integration among civic participation of citizens and their participatory intervention in planning and decision-making policy must have vital consideration in the existence and development of democratic societies.

Going beyond, some questions must be raised, answered and analyzed:

- There are full mastery and skills to ensure independence in decision making?

- Do the government have effective governance conditions?

- Does the situational analysis allow the choice of different leadership standards for different groups without undue of governance? Autocracy, democracy or liberality?

- There are commitment and harmonious integration between delegated authority and the responsibility to be assumed?

- At what levels do they take place?

- There are productivity and intensification in the use of scarce public resources?

- How changing management and conflict management are handled? 
"Citizens' participation in the reflection on the future of their communities" has been an issue of growing interest in the political and media agenda and also of significant scientific interest. The concept of participation is related to "involvement, information, and consultation of the citizen in activities of a decision-making process" (CLARCK, 1994) and it is believed that participatory decisions reinforce the legitimacy of public action, as well as co-responsibility of the various players, therefore, leads to better decisions.

Participatory and democratic management ensures the participation of the population in discussions and debates about the future of the city so that citizens can express their opinion, thus influencing the destiny of the municipality. To this end, the processes for drawing up plans and projects need to provide methods and steps that all citizens clearly understand to ensure that different segments of society could participate in planning and managing urban, and territorial policies. Community participation, as a form of social control, is a mechanism for preventing corruption and strengthening citizenship. Access to adequate information and technical knowledge, for this, are fundamental, and the society should be mobilized for this process, with adequate publicity and respect for diversities.

Ortega y Gasset (1993) refer the individual to the factors of influence that permeate it when he affirms "man is a man and his circumstances". Circumstances are much related to the city where man lives, produces and reproduces. Therefore, urban planning is responsible for valuing the individual and ensuring that urban circumstances should be one of its main goals. The individual resides, as a rule, in the city or urbanized spaces, and the closer it is in the sphere of decisions, more appropriate will be these decisions, as advocates Correa Gomes (2006). But more politically mature cities call themselves, the ability to propose, discuss, formulate, compose, and control the elements of urban planning, taking into account their needs, expectations, the identification of political leaders, and flowing into the construction of citizenship, besides the real application of the concept of democracy. As Harvey (2013) points out, "the dialectic of urbanization and social transformation work in our environment and we both suffer and contribute to its effects... "This ensures the full and free exercise of participatory and productive citizenship contribution.

One could not deny the importance of Public Power in planning. Also, shared management of the city is essential, demonstrating in this way the potential of public hearings in the efficient management of urban spaces, providing transparency about political decisions, aiming social justice, also highlighting the essentiality of effective popular participation in the Master Plan elaboration and updating. Legitimizing the performance of the public power must be closely linked to social desires. Also, participatory management of the urban environment is directly related to the construction of an integrating society, whose management should be directed to the implementation of effective public policies to guarantee the well-being of all.

When people effectively participate in decision-making interest in cities, they feel more responsible for the outcome of their decisions, providing a political maturity of the population. With this, the population will act more closely on urban issues, acting as public urban planning (SOUZA, 2011). Participation implies, in fact, the creation of new paths or 
new relations between the civil society and the public sphere. It depends on four factors (CUNILL, 2005; TENÓRIO; COSTA, 1999):

- Levels of participation: political scope; management scope public;

- The character of the intervention of the citizens in the activities and/or public organs: consultative and/or advisor; resolution and oversight; participation in implementation;

- The character of subjects' social actors: direct/indirect;

- Origin of the impulse to participation: citizen action/citizen involvement.

According to Tenório and Costa (1999): "Pedro Jacobi (1990) emphasizes that the participation of citizens should define public obligations and legal mechanisms, such as municipal interest entities, the city and district advisory councils, the initiative of citizens and popular consultations by district". This perception denotes that group of citizens can be represented by entities or social movements, added to the channels of public power, characterized and defined as democratic participation. This principle is demonstrated by Souza (2011) in addressing the issues of delegation and representation in which it establishes the impossibility of direct participation of all the people in the same place in a contemporary city. He suggests the institution of delegations as an alternative, emphasizing that it "does not hurt the essence of direct democracy (keeping the distinction between delegation and representation, and provided that the delegation is closely controlled by the grantors of the delegation, that is, the body of citizens)". However, the same author asserts that the rescue of the strictly direct participation is made possible with the use of current communication and information technologies, dispensing thus the need for delegates.

On that account, it is assumed that for the healthy growth and sustainable development of cities and urban areas it is indispensable that the Public Power establishes, implements, and monitors the tools and instruments of urban planning and regulation, with the support and participation of the population in an increasingly effective way.

\section{HISTORICAL CONTEXTUALIZATION, CURRENT URBAN POLICIES AND THE EXPERIENCE OF THE COMMUNITY PARTICIPATION IN THIS PROCESS}

\section{Brazil}

Brazil is a continental country. It has $8,516 \mathrm{mi} \mathrm{km} 2,209,3 \mathrm{mi}$ inhabitants, resulting in a population density of 24.6 inhabitants $/ \mathrm{km}^{2}$. There are 5,570 municipalities within 27 states, and its GDP per capita is about 9,121.41 USD.

Urban Planning in Brazil began to be treated, in a rather incipient way, in the 1930s, with Agache Plan. This was the first proposal of intervention for a Brazilian city, Rio de Janeiro, and included the planning of public transportation, water supply, protection of green areas and housing. 
The increase of the population contingent in the urban areas operated a transformation of the cities, turning them into complex spaces of personal interrelationships and deep interventions in nature. Urbanization, as a population concentration in the urban area instead of the countryside, is seen in Brazil as a process some ways disconnected to the development of urban infrastructure. It led to a complete disparity between urban expansion and guarantee of fundamental rights, generating "renewed processes of social exclusion, housing crisis, spatial segregation, urban violence, and environmental degradation" (FERNANDES, 2006, p.3).

The disordered growth of Brazilian cities, caused in part by the State's omission in the efficient planning of urban policies, has thus resulted in a population density that generates environmental impact and social exclusion. Between 1960 and 2010, the Brazilian population increased from 70,2 to 191,7 million people, and the urban population increased from $44 \%$ to an impressive $84 \%$. These numbers underscore the growing need to engage with issues related to the development and management of cities in the country since the 1960s.

In the 70s the urban population in Brazil surpassed the rural one. The disorderly growth of cities began to create problems even more complex and urban planning arisen as an important tool to try to solve them. Between the 70s and 80s prevailed the planner's technocratic vision: a good plan was flat technician, built from data and rational logic. However, as it did not respond to the most crucial demands of the real needs of the population regarding relationships, mobility, built environment, dignity, and quality of life. So, the urban environment is therefore conceived as a space violating human rights due to the flagrant state inefficiency of taking actions to implement essential public policies to the proper city development. Consequently, the city started to develop according to the housing market and the poor, now conceived as a mere consequence of the process of urbanization and economic development, was relegated to more remote areas, less urbanized, sometimes without any suitable urban infrastructure.

Planning as a matter of fact has to be conceived as a guiding tool for state actions in correcting the failures resulting from the disordered urbanization process, as well as in the achievement of social rights, of sustainable development, according to Marques when states that "planned cities mean better quality of life for future generations" (MARQUES, 2010, p.188).

Urban policies planning must always be based on a dynamic perspective so that it can also be efficient about social anxieties that change and evolve in a short time. In this regard, Alochio affirms that the actions of the State for planning must be oriented towards the future, to respond to social dynamism, taking into account "the temporalities of the economically hegemonic elements of the city" (ALOCHIO, 2010, p.87).

Instability, inconstancy, and immediacy are factors that directly affect the process of urban planning and cause the discontinuity of the action already planned and, much because of that, creates irremediable social discredit. The ability to adapt and enforce planning policies through Administration is largely driven by the promotion of greater openness of its actions, aimed at the recipient of the administrative acts. Consequently, 
it encourages the dialogue and, with building policies and drawing up plans in which all they are touched, all the main actors must be involved. The urban planning has the responsibility of valuing the individual and the community as a whole, and guaranteeing urban development should be one of its main objectives.

Urban policies planning, as one of the functions of the Public Power aims to direct the State's action in the effective attendance of the indispensable elements to the guarantee of a dignified life to the individuals, reason why the popular participation in the political decision making is elementary in the precise observance of social yearnings. Popular participation in the planning of public policies consecrates the observance of the fulfillment of the functions of the State in consonance with the interests of all the individuals, able to construct an integrating society, attentive to all the peculiarities of a given locality, also paying attention to the temporalities to which it is subject.

Therefore, in 1988, the new Brazilian Federal Constitution affirmed the principle of participation as a premise for the elaboration of public policy and highlighted the Master Plan as a basic instrument of Brazilian urban management. The Master Plan deals, since then, with issues such as compulsory installment, building and use of property, right of preemption, and onerous grant of the right to build, right to costly alter land use, consortium urban operations, and transfer of the right to build. In such a way, the power was decentralized, increasing the responsibility of municipalities. Since a greater autonomy and independence for local management, the Master Plan was reinforced as an instrument for urban planning and advocated democratic management in all stages of urban planning references. The implementation of the 1988 Federal Constitution supported the model of pure representative democracy, with the insertion of the concept of democracy participatory, with the establishment of several legal institutes that enable its practice, like the plebiscite, referendum, and popular initiative (LUCENA, 1991 apud TENÓRIO; COSTA, 1999).

Urban planning emerges then as an essential instrument to the transformation of an unsatisfactory urban reality. In 2001, the Estatuto da Cidade (Bill \#10.257) settled that must have a Master Plan all cities with more than 20,000 inhabitants, members of metropolitan areas or urban agglomerations, or even cities in which the Government intends to use instruments such as compulsory installment or building, progressive taxes (IPTU) in time, and expropriation with payment through public debt securities. Eight years later, in 2009, among the 1,600 municipalities with more than 20,000 inhabitants, only 200 (12.5\%) had not yet a Master Plan. From a positive perspective, this can be seen as a small number, considering the extent of the country, the relatively low GDP, its recent independency, the short time that urban planning is treated more effectively in Brazil, the differences among regions.

In a sense that the strengthening of popular participation in the management of the city allies, by obvious, the effective guarantee of fundamental rights expressly foreseen in the Federal Constitution, such as the right to a quality education and information, induces the reconstruction of a society with more justice, hence, individuals pursuit directly the common well-being, thus erecting the ideal city sought by the citizens. 
Counting the popular participation in the planning of urban policies aiming at the efficient management of the city, Habermas (2012) offers in Theory of Communicative Action the bases for building an integrative society through intersubjective dialogue amid social actors. Seeking to achieve integration among the various sectors involved in the constitution of the city, the main actors involved in the regulation and urban planning tools in Brazil are the Federal Government, the Municipalities, the citizens, and the private companies.

The Federal Government establishes by law the municipalities obligation to prepare and approve a Master Plan to the full compliance of the city social functions and urban property. The Municipalities concentrates the attributions of legislating in urban matters for their territory through the Master Plan (rules, parameters, incentives, and instruments for the development of the city), as well as urban investments and interventions, such as public facilities and infrastructure. The Master Plan must have democratic management, with the population participation as well as representative associations of the various segments of the community. The citizens and private companies vote and contribute on some of the decisions about the instruments of urban planning, such as 'Participatory Budgets', fulfill requirements and take actions following the directives and incentives of the Master Plan.

At this point, it is important to emphasize once again that citizen participation has a vital role in city planning since it is through its recognition as a social actor that the individual is able to contribute to the development of the urban environment, reaching adequate levels of social inclusion and preservation of the environment, in a true space of coexistence worthy of individuals. To that end, Habermas asserts that the legitimacy of legal norms stems from the "public autonomy of citizens, who must ultimately decide, and as legal actors equal in rights, the criteria of equal treatment" (HABERMAS, 2012, p.154).

In this context, the construction of an integrating city, the theory of communicative action proves to be fundamental in the analysis of the functions of the democratic State of Law, concerning the achievement of fundamental rights constructed throughout the continuous dialogue of individuals who recognize each other as social agents, and subjects of rights.

In the terms asserted by Mencio, the Brazilian State is founded on popular participation once the people are "titular and the chosen entity for the exercise of the political power of the State" (MENCIO, 2007, p.39). For the purpose of guarantee the development of the social function of cities, the democratic State of Law presupposes the popular participation in elaborating and controlling the political decisions taken by the Public Power, since the legitimacy of its action stems from the people themselves, allows society to be an active part in environmental policy decisions, with the possibility of reaching "a common understanding that will guide public policies.

The objectives of Urban Planning in Brazil are to order the full development of the social functions of the city and urban property. The country, therefore, is an example of community participation in the process of urban planning and the development of the cities.

The involvement and committed participation of society with positive results must be present from the very beginning of the preparation of public policies, and in the budget 
priorities. Brazilian public management has instruments for the effective participation of society and its tools had no significative changes since its implementation. The Urban Policy Bill 10.257/2001 provides a merely illustrative list of instruments for the achievement of the democratic management of cities, such as:

- Collegiate bodies for urban national, state, and municipal levels;

- Debates, hearings, and public consultations;

- Conferences on subjects of urban interest, at the national, state, and municipal levels;

- A popular initiative of the bill and urban development plans, programs, and projects;

- The management participatory budgeting at the municipal level;

- Metropolitan regions and urban agglomerations.

It is essential to address these tools as ways of to contextualize and to participate, since political and legislative divergences in interpretation, application, and priorities are presented as one of the main problems in the participation, following Bucci (2003, p. 330-332):

Collegiate bodies for urban national, state, and municipal levels to draw up common guidelines for the solution of urban problems in each level, in addition to providing an exchange of experiences and sum of efforts to solve common urban problems. In municipal level:

- Created by local law, shall include at least composition, mandates, nomination form, attributions, consultative and/or deliberative character, financial resources;

- It must be determined whether they are joint or tripartite;

The Council of Cities, through Resolution \# 13 (June 16 $\left.6^{\text {th }}, 2004\right)$ recognizes the social representation in these Councils, whose main task is to evaluate, propose, debate and approve the urban development policy together with the public power and civil society. The composition of these councils should provide a mixed representation according to Avritzer (2002) as mixed institutions, formed in part by representatives of the State, partly by representatives of the society, with consultative and/or deliberative powers, which, time, elements of representative democracy, and direct democracy.

Debates, hearings, and public consultations, as interlocution channels between the State and society, usually present in the discussions of the Municipal Master Plan the direct channels of communication between public power and civil society that can achieve a high degree of social participation, especially at a municipal level. However, it is expected that there will be wide dissemination before the due date to ensure satisfactory popular participation. Public hearings are open public meetings held at a councilor request to instruct legislative matters in process, as well as any matter of public interest relevant to the Commission affairs. Democratic public hearings, according to Tenório and Costa (1999), although not necessarily imply in the direct decisions by population, it represents 
a way of making the state share the power in a more democratic and accessible way. However, such sharing should ensure effective opportunity for deliberation and not just a public consultation, given that democratic management encompasses real and full citizen participation in politics. For what it is important to enabling the participants to act as integral parts in the decision-making process.

Conferences on subjects of urban interest are important for establishing major urban policy frameworks, such as the formulation of Executive Plans, its revision (which should be preceded by an evaluation) and the intersectoral debates. These conferences should cover the largest number of people, representative of the various segments of the community such as entrepreneurs, residents, workers, environmental protection agents, and other diffuse and collectives.

Popular Bill Initiative and Development Plans, Programs and Projects urban evolves the popular initiative through the presentation of demands that will give rise to a bill project in the Deputies Chamber, after subscribing to at least $1 \%$ of the national electorate, distributed by the least five States, with not less than three-tenths percent of the voters of each. At the municipal level, popular initiative occurs through the mobilization of at least $5 \%$ of the municipal electorate to promote directly to the Legislative power a claim for consideration, approval, and consequent enactment by the Municipal executive. Its is a way to overcome any deficiencies of the two powers directly involved in municipal urban planning (legislative and executive). It exposed often the ineffectiveness of some representative powers of society currently, attesting to the serious crisis of the national representative democratic model.

The population deciding the Participatory Budgeting (Orçamento Participativo) emerged in Brazil in the late 1980s and incorporated into city management. It consists of notifies the society of what work and services should be prioritized in the allocation of municipal resources. The Sustainable Cities Network (SCN, 2018) defines it as a dynamic planning process of the municipal budget, which adjusts periodically to the demands and facilitates the debate between the municipal government and the population. In assemblies, the population elects representatives (or delegates), in proportion to the number of voters, and it is up to these representatives to organize discussions on the priority of each neighborhood. Subsequently, there is also the election of directors, who will accompany and participate, together with the City Hall, the budget piece (SOUZA, 2003).

The process of Participatory Budgets begins with preparatory meetings when the Executive is accountable for the past fiscal year and presents the guidelines of the investments and services for the following year. At the later stage, the regional assemblies establish priorities for the municipality to elect their councilors and define the number of delegates to their respective regional forums and thematic discussion groups. The innovative component of the Participatory Budget as a process that combines democracy with representative democracy, consists en citizens participating directly on decision-making processes, through regional assemblies, besides authority to its elected representatives to act in the so-called deliberative phase. Given the proposed distribution of budgetary resources, the Participatory Budget is also a form of democratic inclusion of the various 
segments of civil society, since it guides the government in sharing the power of deliberation through a direct choice of representatives, acquiring a character of co-management of public resources. Almeida (2005) also looks at the impact of adopting this system on the visibility of management that together with other participatory experiences highlight directing and reorientation of goals that interest to all civil society. Almeida (2005) points out, however, that the implementation of this tool contributes to significant changes at the administrative level, but does not change reality if there is not a political will for popular inclusion and effective incorporation of representation to the political system. If there is no manipulation, but rather an openness to cooperation, the viability of the articulation between public power and society happens. The Participative Budget cannot be understood as only a process of participation, elaboration of demands, or deliberation of citizens. It should be understood as a democratic institution that allows the resolution of disputes, places groups divergent together and allows political debate (WAMPLER, 2003).

About popular referendum, and plebiscite, although not explicitly foreseen in the chapter on the democratic management of the city (articles 43/46) in the Estatuto da Cidade, also legal and political institutes can be considered instruments of democratic management, being them the popular referendum and the plebiscite (Article 4, subsection V, " $\mathrm{s}$ " of Bill \# $10.257 / 2001$ ). Both should be considered consultations to the population to deliberate on marked relevant matters, of a constitutional, legislative, or even administrative issue. The plebiscite is summoned before a legislative or administrative action, and the people, by vote, approve or deny what has been submitted to it. The referendum is convened after a legislative or administrative act, fulfilling to the people its ratification or rejection (Article 2 of Bill \# 9.709, November $18^{\text {th }}, 1998$ ).

\section{Portugal}

It is one of the smallest countries in the European Union. The country has 92,212 $\mathrm{km}^{2}, 10,562,178$ inhabitants, resulting in a population density of 115.3 inhabitants $/ \mathrm{km}^{2}$. It has 20 states and 308 municipalities, and a GDP per capita of 29,239.00 USD. Nevertheless, it is a country with strong problems due to regional differences between the interior and the coast, as the increasing number of elderly people and the huge area of burned forests.

Portugal is a unitary state with two levels of government: the National level and the Municipalities, plus two autonomous regions (Azores and Madeira). The spatial dimension of the National Government's function is stated at the National Programs of Spatial Planning Policies and Special Programs for Particular Regions. The National Government also supervises the Regional Coordination and Development Commissions, coordinates national and local policies related to environmental and spatial planning, and prepares the Regional Spatial Development Programs. The Municipalities are responsible for the most important instrument, the Municipal Master Plan (PDM). Several other public authorities and public companies affect land-use policies in Portugal, most of them controlled by the National Government. 
Historically, the first General Urbanization Plans were made in Portugal at the same time as in Brazil, in the 1930s, more precisely in 1934. Then, from the middle of the 1960s, in 1965, and 1967, to the beginning of the 1970s, in 1973, the plans included the consideration of regional development.

By the 1976 Constitution, the urban planning in Portugal assumed a new character, in a similar way to what it took in Brazil little more than a decade later with the 1988 Constitution. After the fourth constitutional revision resulting from Bill 1/1997 (September 20 ${ }^{\text {th }}$ ). This gave a "real qualitative leap forward" in the constitution of the urbanism (CORREIA, 2008), and several provisions have been made to the constitutional text regarding urban planning and land-use planning, the interested in the elaboration of urban planning instruments, and other instruments of physical planning of the territory (65, paragraph 5).

Silva (2012) declares that the Rule of Law as the Liberal State of Law or as the State of Law does not always characterize the Democratic State, since it is based on the principle of popular sovereignty, this imposes the effective and active participation of the people in the participation that is not exhausted, as we shall see, in the simple formation of institutions represent a stage in the evolution of the Democratic State, but not its complete development.

Unfolding the principle of the Rule of Law, we find, as a sub-principle, the principle of legal protection and procedural safeguards, in other words, the existence of an individual legal and judicial protection without gaps which demands, among other dimensions, a fair administrative procedure that includes the right of the particular in the procedures in which it is interesting (CANOTILHO, 2014).

The Democratic Rule of Law consists in the creation of a new concept, which experiences of the State of Law and of the Social State, called 'State of Legitimacy' establish a process of effective incorporation of the population into the mechanisms of control of decisions, with real participation in income production (SILVA, 2012).

Following this process, from the beginning of the 1980s, issues about the environment were addressed, and nationwide planning presented restrictions for agriculture and preserved land (RAN/REN). In 1988, another coincidence with the historical context of urban planning in Brazil, at the same time as the Brazilian Constitution, Urban Renewal Programs were developed in Portugal (PRAUD/RECRIA) and a few years later, in the early 1990s, the first generation of Municipal Master Plans was promoted. Then, after the PDMs, came also the PROSIURB program, to promote strategic planning (1994), the POLIS program, to renew the urban centers in mid-sized cities (2001), and the SRU programs to renew the historical centers (2001).

The main objectives of urban planning tools in Portugal are to strengthen the strategic dimension of the planning process, regulating specific land uses, and along with its development, one of its challenges is to format inter-municipal entities for joint planning. As in Brazil, the actors involved in this process are the Central Government, the Municipalities, and the citizens and private companies.

The Central Government has a role to create a major plan for the entire country by giving national orientations and objectives. It also develops an inter municipality plan for further concretization. The Municipalities have to apply the guidelines decided by 
the Central Government into more specific planning. They must create the Master Plan for the municipality and then establish Detailed Plans for some areas. The citizens and private companies are obliged to follow the directives stated in the Master Plan from the Municipality.

In Portugal, there are no regular and organized practices for the reflection on the future of communities and there is some evidence of increased difficulties in organizing it collectively in a participatory manner. At the same time, there is a progressive separation between the citizen, the community in which they are inserted, and their legitimate representatives that have been manifested worryingly and persistently. Given the recognition of this challenge, there have been some efforts (discursive, and operative) that point to the need to reverse the situation. However, there is a significant difference between the pretension or the desire and the action, so that this difficulty should justify greater attention on the part of the responsible ones and citizens. The city of Aveiro is the one that has been more mobilized in the sense of seeking and achieving this participation of the communities in the process of urban planning, with the support of the University of Aveiro and its researchers. According to Mora and Moura e Sá, from University of Aveiro, in Portugal there are some myths about community participation in urban planning that should be decontaminated to encourage and contribute to its development:

Chart 1 - Representation of Fundamental Parameters of Urban Strategic Planning.

\begin{tabular}{|c|c|}
\hline Myth & Reality \\
\hline Citizens do not participate (for more that we strive). & When properly mobilized, they participate. \\
\hline Promoting participation is Inform. & $\begin{array}{l}\text { It is very important to inform the citizens, but it is not } \\
\text { enough. It should be also dialogue, share choices, engage } \\
\text { for something more. }\end{array}$ \\
\hline $\begin{array}{l}\text { Already passed the opportunity, the term of the public } \\
\text { inquiry, was not attentive, now no use. }\end{array}$ & The defense of the public interest has no time limit. \\
\hline $\begin{array}{l}\text { It only makes sense to promote concrete projects. } \\
\text { Discussing goals is very abstract. }\end{array}$ & $\begin{array}{l}\text { It is important to give frames of reference to support the } \\
\text { discussion of objects, to discuss what we want collectively } \\
\text { as a community or city before discussing the concrete } \\
\text { proposals. }\end{array}$ \\
\hline $\begin{array}{l}\text { Participation seeks consensus and it is not possible to } \\
\text { place everyone according. }\end{array}$ & We must look for compromises. \\
\hline Participation does not change anything. & $\begin{array}{l}\text { It may not change the decision, but it does influence the } \\
\text { context. }\end{array}$ \\
\hline $\begin{array}{l}\text { The participation ends in the conception of the plan/ } \\
\text { project. }\end{array}$ & It does not have to end; it can mobilize for action. \\
\hline
\end{tabular}

Source: OLIVEIRA, LOPES, COLENCI, SOUSA, 2015.

In Portugal, the instruments of participation in urban planning are varied, even established as more procedural or formal (that is, inserted in administrative procedures) rather than organizational (that is, inclusion in the definition of strategies and decisions of planning). The constitution of the municipality of the city is not always integrated into organic and effective citizenship participation. This does not mean, however, that they 
do not exist, but their creation, functioning, and relationship with local authorities do not follow a specific legal model.

In the scope of the municipal Master Plans, a central figure in the definition of and the regulation of conditions of use, occupation and transformation of the soil, the institutionalization of a conciliation phase was accompanied by the creation of a body constituted and intended for this purpose by order of the Minister responsible for territory - the Joint Coordination Committee. Its composition should initially translate into "the nature of the interests to be safeguarded and the relevance of the technical implications to be considered, integrating technicians from direct administration services or indirectly from the State, the Autonomous Regions, the municipality and other public bodies whose participation is advisable under the plan, as well as representatives of economic, social, cultural and (Article 75 (2) of the RJIGT, in its initial version)".

This entity then embodied a mechanism of cooperation among the stakeholders, included the participation of private organizations in the elaboration of the municipal director plans. However, the amendment to RJIGT promoted by Decree-Law \# 360/2007 introduced a new article (Article 75-A), according to which " the monitoring of the preparation of the municipal master plan is ensured by a with purely public composition." This eliminated the possibility of private entities - although only those whose intervention was considered relevant and useful by the City Hall - if they could be through an opinion issued at the same time as the other public entities, as well as meetings are held to reach a concerted solution.

Even at the national level, despite the fact that there are relevant advisory committees with the participation of representatives of civil society (as is the case with the Economic and Social, and the National Council for Environment and Sustainable Development), the participation of private entities has been excluded from the discussion of the strategic aspects and problems related to the occupation of the territory, as demonstrated by the composition of the Territorial Coordination Council recently created that consists only of state and infra-state representants (Resolution of the Council of Ministers \# 16/2014, March, $\left.5^{\text {th }}\right)$.

This does not mean that there are no 'pilot' experiments (without legal welcomes) that deepen the methodology of Working Groups with the representation of local actors, as described by Guerra (2002) within the framework of the Strategic Plan for the Region of Lisbon West and Tagus Valley, for a horizon of 2000/2006. For the author, the experience, in addition to being a positive example of the socialization of information and consequent implication of the authors, allowed to construct an empirical typology of collective action, all of them with great participatory impact: "(a) claim action; (b) critical action; (c) local and/or global participatory management action and of concertation; d) pedagogical action and/or innovative".

Nevertheless, other legal and administrative tools promote participation at the local level, as shown below: 


\section{- Public Consultations:}

The participation that is cured at this point is closely related to when individuals are involved in the planning process, offering their contributions and suggestions or submitting complaints to the state authorities. Initially, only the public stakeholders inquiry at a later stage in assuming more or less complete anticipation of the definitive proposed plan. However, the inadequacy of this approach was acknowledged, the limited time of stakeholder involvement could turn the process inefficient and useless. In short, closely associated with these extensive participation-hearing mechanisms of the stakeholders concerns, their right of information cannot be overlooked, due the duty to weigh complaints, observations, suggestions, and requests for clarification. Additionally, the duty to provide a reasonable response (and/or formalization and publication of the weighting report) which is incumbency of the City Hall and assess whether or not that consideration had a place. Yet there is the promotion of the dematerialized dimension of planning, like the plan documents (in approval and already approved) and online forms of participation, in order to make it more comfortable and inviting the formulation of suggestions by individuals, since it does not preclude participation in the traditional ways (in writing or personally). The aim is to strengthen the right of all stakeholders to participate at the defense of selfinterest (or in the defense of collective interests), at times in which it assumes its importance, ensuring that participation takes place in the most effective phases. From the point of view of the Administration, public consultation is an important tool for collection of citizens material to integrate in the planning, in safeguarding their complaints, suggestions, and observations. Finally, it should be noted that the centrality of the public consultation (and access to information) in Portuguese law is not the isolated result of intern constitutional process, but rather the consequence of a set of international and transnational legislation, such as those resulting from the Aarhus and the environmental legislation of the European Union, first and foremost as regards environmental assessment.

\section{- Urbanistic Contracts:}

Despite the little practical relevance of concertation in the procedure of planning tools, the same can no longer be said of contracting for planning itself. After a troubled initial period in which it was questioned whether it was possible for private individuals to influence, by negotiation, the definition of municipal policy and urban planning options - due to the lack of legal provision for this possibility and the doubts related to their lack of transparency and control - the legislation expressly accepted this possibility (with the amendment carried out by Decree-Law \# 316/2007, of September, 19 ${ }^{\text {th }}$, at RJIGT). In Portugal the terms in which those interested in a planning procedure can be contracted with the Municipal Administration to regulate the beginning of that procedure or the terms in which it should be carried out (for example, reclassification of land use, or the construction indices to be included in the plan). From the procedural point of view, the 
conclusion of a planning contract is also subject to a specific procedure, involving moments of informed deliberation on the public convenience of the conclusion of the contract, adequate publicity, and particularly stakeholders in that procedure. This is the only way to ensure that planning contracts can serve as a suitable mechanism to positively influence the planning process.

\section{- Popular Initiatives:}

Portuguese administrative law does not grant private individuals a right that implies a duty of openness on the part of the procedure for drawing up the plan they have requested, but rather the right to city council to consider its proposal, and inform the stakeholders the final decision and the grounds for it. With regard to other forms of citizen participation with possible promotion of tools of urban planning, it is necessary to note that in Portugal, following a constitutional provision (Articles 167 and 240 of the Constitution of Portuguese Republic), the recourse to the popular legislative initiative has been regulated. It is still possible to resort to popular referendums and, in particular, to local referendums. According to Organic Law \# 4/2000, August, $24^{\text {th }}$, the local referendum can only be concerned with issues of relevant local interest which should be decided by the autonomous municipal or parish, and which are integrated into their competences, either exclusive or shared with the State or the Autonomous Regions. However, urban planning is certainly one of these matters, especially considering the competences of municipalities in municipal planning of the territory. Indeed, local referendums cannot replace or overlap planning skills, which are based on a complex task of balancing interests. However, they may prove to be precious mechanisms for making difficult decisions about the occupation of the territory.

\section{- Participatory Budgeting:}

Participatory Budget Management has been applied in Portugal, even though this implementation is characterized by some dissemination and, in some cases, longevity (some budgets being considered as pilot projects and not as mechanisms of municipal public management). Still, the subsisting (and, in some cases, reinforced) participatory budgets have contributed to a greater rapprochement between local representatives (as municipal public policies) and the community at large, improving the processes of communication and decision-making in a logic of openness and cooperation (if not co-decision). At the same time, they promote the exercise of active, open and contributing to the formation of a culture of rights that is not dissociated from the inherent duties and promoting the formation and development of civic movements associations. Finally, they contribute to the good governance of administrative the effective use of public resources, the definition and articulation of strategies and intervention priorities, and the approximation of these to the wishes of individuals. 


\section{COMPARATIVE ANALYSIS BRAZIL X PORTUGAL}

In both Brazil and Portugal, the Master Plan is the main instrument for planning and regulating cities and the urban environment. This tool materializes the urban management of the city, concretely defining instruments of urban intervention and guidelines, besides defining criteria for land regularization, so that the city and urban property can perform their social functions, ensuring the quality of life, social justice, and sustainable development.

Turning to popular participation in urban planning law in Brazil, Bill \# 10.257/ 2001 (Estatuto da Cidade) which made it possible to social participation as a normative basis of urban policy, in addition to ensure a broad discussion with society and the clarification of information for the understanding of the parameters that guide local planning during the preparation and implementation of the Master Plan (LIMA, 2012). This Participative Master Plan is a tool that adopted a new form of urban management, bringing the stakeholders needs within the main instrument of urban planning (GONDIM; LIMA; MOREIRA, 2005). The recent and controversial act of the Brazilian federal government, Decree \# 8.243/2014, in its article 1, instituted the "National Policy on Social Participation - PNPS, to strengthen and articulate mechanisms and democratic instances of dialogue and joint action between the administration federal public and civil society."

In Portugal, the same emphasis on popular participation in urban development law has been applied in urban planning legislation. Recently, Law \# 31/2014, May, $30^{\text {th }}$ (that revoked previous Law of Bases of the Planning of the Territory and the Urbanism, approved by Law \# 48/98, August, 11 ${ }^{\text {th }}$, and which establishes the General Bases of the Policy Soil Public Administration, Land Management and Urban Planning) considered as a fundamental principle in these areas the public participation as well as private interests (Article $3(1)(\mathrm{g})$ and (h)). It adds, in Article 49, in order to operationalize this principle that "The procedure for drafting, amending or revising the programs and plans territorial guarantees the individuals the general guarantees that the law confers on them, information and the means of effective public participation, as well as the such as the right to submit observations and suggestions to the responsibility for drawing up and consulting the respective dossier, in accordance with of law."

However, even with the assumption of population participation in the plans (both in Brazil and Portugal), the effective promotion of popular inclusion in the decisionmaking regarding the planning formulation and implementation of measures is still a challenge. The reasons for this difficulty are pointed out by Lima (2012) as: population is disconnected from associations, which act effectively in the search for rights; lack of technical qualification of civil society representatives in dealing with the machine stateowned; with this, the subjects have compromised the autonomy and the quality of the participation, generating deep asymmetries in the plane of knowledge, which can lead to an imbalance of power that generates the reproduction of mechanisms of domination and exclusion in spaces that, at less, in theory, should be democratic.

It is a fact that the Participatory Governance creates important mechanisms to encourage the participatory approach of a city. However, the operation of these tools can 
only be achieved through the creation of networks of local actors to gather knowledge and public policies that solve, in fact, local problems.

In the end, comparing Brazil and Portugal, although the two countries have very different features and nature, one could see that the recent history and evolution of urbanistic concepts in both countries occur in a parallel and almost concomitant way. Although their dimensions and territorial complexity are different, urban planning and regulation tools, especially the Municipal Master Plan, and the actors involved (State, Municipality, citizens, and private companies) are very similar, as are the concerns and efforts in involve the population in decisions as an important measure for the successful implementation of urban policies. The difference on this point may lie in the fact that Brazil is one step ahead about popular participation in urban planning and participatory budgeting, probably due to the political and socio-economic characteristics of the country, and the needs that this condition imposes on its inhabitants.

\section{FINAL REMARKS}

The construction of a shared city requires community participation to be seen as more than a formal (hearing) or informative mechanism. It is required that popular participation be interactive and based on the ideas of responsibility, cohesion and search for consensus, to institute the processes that reduce the conflicts inherent to the territory occupancy and to promote a real decentralization of decision-making (GALLACH, 2008).

The formal moments of participation are indeed important; however, the competent entities should not rest only in compliance with the legal impositions of participation. According to Jacinto (2001) the democratization of planning means that the Administration and local authorities must actively promote the participation of citizens in the process of drawing up of the plans, far beyond what emerges from the legal landscape.

This implies a change of culture, both at the legislative and administrative levels and in the day-to-day performance of the public authorities with greater or lesser powers to planning, assuming effective social participation as beneficial to public decision-making processes, to hide in the alleged negative points associated with participation.

Regardless of both Brazil and Portugal have already make great efforts in this direction, and the question of community involvement in the decision-making process, urban planning, and participatory budgeting is already addressed and considered (although at different levels, stages, and legal formalization), there is still much to be done in this direction to ensure the effective participation of the population in the construction and evolution of cities.

\section{REFERENCES}

ALOCHIO, Luiz Henrique Antunes - Plano diretor urbano e Estatuto da Cidade: medidas cautelares e moratórias urbanísticas. Belo Horizonte: Fórum, 2010 
AVRITZER Leonardo. Modelos de deliberação democrática: uma análise do orçamento participativo no Brasil. In: SANTOS, B.S. (Org.). Democratizar a democracia: os caminhos da democracia participativa. Rio de Janeiro: Civilização Brasileira, 2002. p. 561-97.

BUCCI, Maria Paula D. Gestão democrática da Cidade. In: DALLARI, Adilson Abreu; FERRAZ, Sérgio (Coord.). Estatuto da Cidade: Comentários à Lei Federal 10. 257/2001. São Paulo: Malheiros, 2003, p. 322341.

CANOTILHO José Joaquim Gomes. Direito constitucional e teoria da constituição. 7.ed. Coimbra: Almedina, 2014

CLARK, Russell D. The Role of Censorship in Minority Influence. European Journal of Social Psychology, v. 24, n. 3, p. 331-338, 1994. doi:10.1002/ejsp.2420240303.

CORREIA, Fernando Alves. Manual de direito do urbanismo. Coimbra: Almedina, 2008

CUNILL, Nuria. Gestão pública e participação. Salvador: FLEM, 2005

FERNANDES, E. Proteção ambiental ou direito a moradia? Um falso conflito. In: FERNANDES, E.; ALFONSIN, B. (Org.). Direito urbanístico: estudos brasileiros e internacionais. Belo Horizonte: Del Rey, 2006.

FIORILLO, Celso A. Pacheco. Curso de direito ambiental brasileiro. [S.l.] : Saraiva, 2013.

GALLACH, Helena Cruz. Conflictos Territoriales y Movilizaciones Ciudadanas: algunas Reflexiones sobre las Formas de Gobernanza Territorial Actuales. Boletín de la A.G.E., n. 48, p. 375-387, 2008.

GONDIM, Linda M.P.; LIMA, Martônio M.B.; MOREIRA, Sandra M.V. Plano diretor participativo: instrumento para democratizar a gestão urbana? In: ENCONTRO ANUAL DA ANPOCS, 29, 2005, Caxambu. Anais ... p. 1-22.

GUERRA, Plano estratégico da região de Lisboa, Oeste, Vale do Tejo 2000-2010. Lisboa, CCRLVT, 2002.

HABERMAS, Jürgen. Teoria do Agir Comunicativo. São Paulo: Martins Fontes, 2012. 2 v.

HARVEY. David. Utopias Dialécticas. In: BOSCH, Eulália (Ed.) Educação e Vida Urbana 20 anos de Cidades Educadoras. Torres Novas: Almondina, 2013. p. 43-50.

JACINTO, José A. Cidadania, urbanismo e democracia: a parricipação pública nas decisões políticoadministrativas. Educação \& Comunicação, n. 6, p. 74-96, 2001.

LIMA, Antonia J, de. Master plans and the dilemmas of urban governance in Brazil. Textos \& Contextos, v. 11, n. 2, p. 362 - 375, 2012.

MARQUES José Roberto. Meio ambiente urbano. Rio de Janeiro: Forense Universitária, 2005

MENCIO, Mariana. A constitucionalidade dos critérios de criação das Regiões Metropolitanas, Aglomerações Urbanas e Microrregiões previstos na Lei Federal brasileira. Revista Digital de Derecho Administrativo, v. 13, p. 161-193, 2015. doi: 10.18601/21452946.n13.09.

MILARÉ, Edis. Direito do ambiente: a gestão ambiental em foco. 7.ed. São Paulo: Revista dos Tribunais, 2011. cap.4.

OLIVEIRA, Celso Maran de; LOPES, Dulce; COLENCI, Pedro L.; SOUSA, Isabel Cristina Nunes de. Instrumentos urbanísticos de participação pública no Brasil e em Portugal. Direito Ambiental Contemporâneo, v. 1, . 141-176, 2015.

OLIVEIRA, Celso Maran de; LOPES, Dulce; SOUSA, Isabel Cristina Nunes de. Direito à participação nas políticas urbanísticas: avanços após 15 anos de estatuto da cidade. Urbe - Revista Brasileira de Gestão Urbana, v. 10, n. 2, p. 322-334, 2018. doi: 10.1590/2175-3369.010.002.ao04.

ORTEGA Y GASSET, José. La cuestión moral. 2.ed. Madrid: Alianza Editorial, 1993. (Obra completa, 10).

RUMBLE, Heather; ANGEOLETTO, Fabio; CONNOP, Stuart et al. Understanding and applying ecological principles in cities. In: LEMES DE OLIVEIRA, Francisco; MELL, I. (Eds.). Planning Cities with Nature: Theories, Strategies and Methods. Amsterdam: Springer Nature, 2019. p. 217-234. 
SCN - Sustainable city network. Disponível em: www.sustainablecitiesnet.com

SILVA, José Afonso da. Curso de Direito Constitucional Brasileiro. 35.ed. São Paulo: Malheiros, 2012.

SOUZA, Marcelo Lopes de. Mudar a cidade: uma introdução crítica ao planejamento e à gestão urbanos. Rio de Janeiro: Bertrand Brasil, 2003

TENÓRIO, Fernando G.; COSTA, Frederico L. Bases conceituais e metodológicas para o estudo da participação cidadã na gestão pública: entre práticas e representações sociais. Cadernos EBAP, v. 93, p. 1-39, 1999.

WAMPLER, B. Orçamento participativo: uma explicação para as amplas variações nos resultados. In: AVRITZER Leonardo; NAVARRO Z. (Org.). A inovação democrática no Brasil. São Paulo: Cortez; 2003. p. 61-86.

Data de submissão: 24/fev./2019

Data de aceite: $27 /$ ago./2019 